\title{
Preserving Identity through Modernity: Dayah al-Aziziyah and Its Negotiations with Modernity in Aceh
}

\author{
Ismail Fahmi Arrauf Nasution \\ Prodi Hukum Ekonomi Syariah, Pascasarjana IAIN Langsa, Aceh \\ ismailfahmiarraufnasution@iainlangsa.ac.id
}

\author{
Miswari \\ Prodi PAI IAIN Langsa, Aceh \\ miswari@iainlangsa.ac.id \\ Sabaruddin \\ Prodi Matematika IAIN Langsa, Aceh \\ sabaruddin@iainlangsa.ac.id
}

Naskah diterima:03-07-2019, direvisi: 24-07-2019; disetujui: 29-07-2019

\begin{abstract}
Abstrak
Tulisan ini bertujuan menganalisa negosiasi dayah di Aceh dalam menghadapi modernitas. Pada satu sisi, dayah perlu menjaga identitas dengan merawat keunikan sistem dan metode pengajaran agama sesuai dengan cara yang telah diajarkan secara turun-temurun. Kajian teks yang ditentukan oleh pengajar (teungku) mulai dari kriteria santri dan sistem evaluasi dan standarisasi kemampuan. Dayah juga merawat identitas dengan membentuk kepribadian santri melalui pembangunan kemandirian hidup di dayah. Sistem dayah telah berhasil melahirkan masyarakat yang memahami Islam secara mendalam, menyeluruh dan jauh dari pemahaman sempit tentang agama. Hal yang lebih penting, pendidikan dayah menjauhkan santri dari pola pikir radikal dan menjadikan mereka manusia yang toleran. Hasil dari studi ini menunjukkan, dayah Al-Aziziyah yang peduli akan modernitas dengan tidak kehilangan identitas serta berhasil menyebarkan ajaran agama dengan baik di Aceh. Negosiasi dengan modernitas juga sedikit membuat Al-Aziziyah harus meninggalkan beberapa prinsip pendidikannya seperti menunda visi besar menjadikan STAI AlAziziyah Samalanga persis seperti dayah manyang yang pernah berjaya di Aceh.
\end{abstract}

Kata Kunci: Aceh, dayah, pendidikan Islam, aziziyah, modernitas, tradisional

\begin{abstract}
This paper aims to analyze the dayah negotiations in Aceh in the face of modernity. On the one hand, the dayah needs to maintain identity by caring for the uniqueness of the system and methods of religious teaching in accordance with methods that have been taught from generation to generation. Text review determined by the dayah teacher (teungku) starting from the criteria of the dayah student (santri) and the system of evaluation and standardization of abilities. Dayah also takes care of identity by forming the personality of the santri through the development of independence of life in the dayah. The dayah system has succeeded in giving birth to a society that understands Islam in a deep, comprehensive and far-reaching understanding of religion. More importantly, dayah education alienates santri from radical thought patterns and makes them tolerant humans. The results of this study show that Dayah Al-Aziziyah who cared about modernity by not losing its identity successfully spread religious teachings well in Aceh. Negotiations with modernity
\end{abstract}


also made Al-Aziziyah a little left with some of its educational principles such as delaying the big vision to make Islamic Higher Educatin (Sekolah Tinggi Agama Islam, STAI) Al-Aziziyah Samalanga exactly like the dayah manyang (higher dayah level) that had been popular in Aceh.

Keywords: Aceh, Dayah, Islamic education, modernity, traditional

\section{Introduction}

Al Makin (2016) on the speech of the appointment of professors presented a paper on the existence and continuity of the mission of the prophets, illustrating why people who claimed to be prophets, their teachings could not develop rapidly like the teachings of Muhammd, Isa, Moses, Abraham and Noah or others. There are several possibilities for this, one of which is because the political structure in the time of "the prophets" after Muhammad did not support the existence of their teachings. So that, the "prophets" career did not last long (Al Makin, 2018, p. 22).

This article wants to see the immunity schemes of Islamic schools in the education system in Aceh, especially traditional Islamic education. These institutions are called dayah. The literature shows that the word 'dayah' refers to the term 'zawiyah' which means an angle in the mosque where religious discussion or education is held. This argument is corroborated by the history of dayah. In the history of Aceh, the oldest dayah is Zawiyah Cot Kala in East Aceh. The educational institution was founded by Meurah Muhammad Amin in the period during the Sultanate of Islam Peureulak. Furthermore dayah education develops in every corner of Aceh (A. Hasjmy, 1981, p. 43).

Besides Zawiyah Cot Kala, there are also other large dayah such as Dayah Seureuleu in Takengon, Dayah Blang Peuria in Geudong North Aceh, Dayah Batu Karang in Tamiang, Dayah Lam Keumeu'eun in Indra Purba Aceh Besar, Dayah Tanoh Abee in Aceh Besar, DayahTiro in Pidie, Dayah Lam Nyong in Kutaraja, Dayah Lam U, Dayah Pante Geulima Meureudu in Pidie, Dayah Krung Kele in Aceh Besar, Dayah Meunasah Blang Samalanga, Dayah Rumpet in West Aceh, Actually dayah is a higher education institution from the traditional Islamic education system. The lowest level sequentially is the rangkang which is found in several places in a village. Next is the meunasah, there is one in each village. Furthermore, there is one balee for several villages. Next is dayah and the highest level is dayah manyang. Many dayah are located in Bayeun, East Aceh, Blang Peuria in North Aceh and Jami'ah Baiturrahman in Kutaraja (Nuruzzahri, 2018, p. 183). In the time of Iskandar Muda, in Jami'ah Baiturrahman who is the highest dayah where high-level 
religious knowledge is taught, also taught sciences such as medicine, history, politics, and philosophy. Teachers there were mostly brought in from India, Persia, Arabia and Turkey (A. Hasjmy, 1978, p. 148).

Related to the concept explained by Al Makin (2016) about the immunity of "the prophets", today in Aceh, the dayah which carries out its activities massively is the one who has the term "Al-Aziziyyah" behind the names of the dayah. The term was taken from the name of a great ulama named Abdul Aziz who was born in Jeunieb Bireuen and later led Ma'had Ulumul Diniyah Islamiyah (MUDI) located in Masjid Raya village Samalanga Bireuen. The dayah is known as Dayah MUDI Mesra Samalanga (Mulyadi, 2015, p. 13).

It was the students of Abon Aziz Samalanga who became the great ulama who returned to their homes to establish dayah by including 'Al-Aziziyah' behind their dayah names.If the development of this school is related to Al Makin's statement about "the prophets", then there are several conditions that make it massive. Among the most important is its political policy which is a consequence of the derivative of the paradigm and the system taught by the Aziziyah school (madzhab Al-Aziziyah).

Aside from Abon Aziz Samalanga, there were many santri (student of dayah) who studied with the great ulama in South Aceh, Muhammad Waly Al-Khalidy or better known as Abuya MudaWaly (Musliadi, 2017, p. 222). One of the most prominent among his santri was Abon Aziz Samalanga. The study of the factors that made Abon Aziz Samalanga very influential needed special space to discuss it. Here I will focus on the education system taught at Aziziyah school specifically and dayah in Aceh generally because this exploration can at least provide two contributions. The first is to answer why the Aziziyah became a very massive and influential "dayah school" in Aceh. The second is trying to answer how the education system in dayah. And finally try to analyze how the dayah negotiated with modernity. The focus of the research is MUDI MESRA Samalanga as the centre of Aziziyah school.

\section{Identity of Dayah Al-Aziziyah}

In general, dayah implements a textual education system and text actualization. That is, santris are directed to learn a religious principle in an orderly manner through the book. The books studied must be organized from the lightest to the highest. The lineage of the hierarchy of the kitab kuning (textbook in dayah) studied must be written by the 'ulama 
mu'tabarah, meaning that it has a clear scientific hierarchy in the Ahlus SunnahWal Jamaah lineage (Sirajuddin, 2010, p. 364).

Each line and sentence from the kitab kuning is explained clearly and thoroughly so that all the ideas, premises, rules, meanings, and systems are actualized until all santris understand well. Simultaneously, the things learned in the kitab must be applied in daily life. To maintain this consistency, students are required to live in the dayah environment. Here in addition to the practice of worship, there is also a culture, ethics and discipline.

Teungku or teacher for a kitab kuning in dayah must have studied with the same pattern to teungku before himself so that he really understood and had practiced the knowledge obtained from the kitab and oral explanations from previous scholars. Such a teacher scheme is important to maintain the validity of a teungku's pedigree. Becoming important is because every sentence and even a word, in the kitab, cannot be interpreted for itself because it is feared that an understanding arises from the intended purpose of the kitab kuning. This makes a teungku in dayah a central aspect of learning. The charisma and prestige of a teungku depart from this point (Hamidi, 1982, p. 59).

That is why the existence of a dayah is very much determined by the teungku who teaches. Usually teungku, which already has many trusted students to help teach it, makes the dayah become more developed. In line with that, usually when the owner of the dayah dies while he cannot find a successor who has the authority of an adequate charisma, his dayah will lose popularity and disperse.

Because a dayah is usually owned independently by a teungku (teungku owner and usually the leader of a dayah is called 'abon' or 'abu') then the ownership of the dayah is inherited to the child or his heir. The problem is that rarely heirs or children are able to have charisma and knowledge that matched with abon, so that the dayah lost popularity and was dissolved. To overcome this problem, usually if an abon (leader of dayah) sees among his children or his heirs that there is no one who is able to make the dayah develop, then he marries his daughter with the most potential santri.

The influence of charisma sometimes made a santri who studied at a dayah from charismatic ulama before himself then went home to open a dayah in his village. Then the dayah became advanced while the dayah where he had studied became receding to disappear slowly after his teacher died. 
There is a unique phenomenon in the process of birth and the maintenance of immunity of a dayah. Usually, ulama who has returned to study from a science which is known to have advanced knowledge does not necessarily establish dayah but the citizenry with his initiative to send his son, himself to establish a hut as a dormitory and bale (hall) not far from the house of the ulama. While the ulama is only busy with himself in worship and remembrance (zdikr) and occasionally interacts with the surrounding community.

Departing from this initiative, the dayah slowly became large and developed. Referring to the scheme of the existence of the prophets described by Al Makin, the existence of a dayah became possible, one of which was because the cleric was settled. And usually, he stays in his wife's family's house or sets up a new home not far from his wife's family's house. This is consistent with the tradition in Aceh that after marriage, a man lives in his wife's house or builds a house not far from his wife's house.

Meanwhile, for the ulama who chose the way of life by traveling from one place to another, even though their knowledge could be more, they did not establish dayah. In this case, one problem was answered why Al-Aziziyahschool became massive because, Abon Aziz Samalanga, to students who were considered to have the ability, advised them to establish a dayah in the place where he had settled after completing his study at dayah. The will motivated students not to resort to wandering but focused on establishing and managing dayah. (Kurdi, 2015, p. 13)

Kitab kuning that was studied at a dayah was very dependent on the level of the book which was mastered by the ulama (Martin Bruinessen, 1990). That is, every santri is taught starting from the lowest book concerning fiqh, akhlaq, tajwid, tauhid. Sometimes the basic kitab have been studied in the meunasah and balee. Then the advanced kitab is studied in dayah. But at a small dayah also teaches meunasah and balee levels (Zarkasy, 2006, p. 162).

After the highest kitab that was able to be taught at a dayah was completed, a santri could continue his education in another higher dayah level. The santri can also serve in the dayah hearing teaching lower kitab and repeating the knowledge that has been learned. He can also return to his village to teach at meunasah and rangkang (Zarkasy, 2006, p. 151).

Dayah is different from modern pesantren (Islamic boarding schools). In pesantren, besides teaching religious education with a model of reading and analyzing text, it also includes secular school (sekolah) lessons (Saifuddin, 2016, p. 3). But the pesantren is 
different from the madrasah (Islamic lower and middle education). Even though it is categorized as a madrasah, pesantren continue to apply religious learning by studying the kitabkuning. Madrasahlearn religion instantly through textbooks.Pesantrendo not implement a system of in-depth studies of kitabbecause they have other demands, namely the subject of learning as learned at sekolah.The similarity between the dayah and the pesantren is equally demanding that the santri live in the location of education (Maksum, 2016, p. 15). In pesantren, food for santris is provided by paying money. However in dayah, santris cook and wash their own clothes.

The pattern of life of santri in dayah which requires independence, hard work, discipline, and orderly worship make the dayah education a perfect educational system because it does not only prioritize clear and profound text mastery but also orderly practice. Because science is not only studied with the five senses but also with the whole self which must be through practice and appreciation (Muthohar, 2016, p. 55).

Knowledge, charity, loyalty, service, solidarity, togetherness, courage, honor and patronage are the characters inherent in santri. It all becomes the main aspect that must be owned by a human being and is difficult to form outside the dayah education system. In pesantren perhaps santris are also required to be disciplined, respectful, have mutual respect, but dayah are superior in this matter because they live not as fancy as modern Islamic boarding school (Ma'rifah, 2015, p. 34).

At dayah, santris must do everything themselves including cooking, washing and even producing something to cook. Usually, santris are simultaneously involved in plowing fields and fields belonging to Abon. Usually, the fields and fields are endowments or borrowed land from the community intended for Abon (Zarkasy, 2018, p. 162).

If a village or several villages (mukim) do not have ulama, then they will persuade anulama who has the knowledge to live in their place. To the ulama, if he is not married, then marry the most beautiful woman in the village. To be provided with a place to live, a dayah building was formed in the form of bale houses and several booths. The cleric was also given rice fields and fields to be managed to meet their daily needs (Hamidy, 1982, p. 25).

At dayah, santris education is free of charge. But they have to do everything independently. The Dayah does not provide the same diploma as the school to be used to apply for several jobs. But dayah has formed an ideal human being who can be the 
successor of the ulama. They are the hope of illuminating human life.With all the uniqueness and advantages of the education system in the Islamic boarding school, it can be said that only those who truly study Islam ideally. Islam prioritizes charity rather than ideas (Iqbal, 2016, p. 1).

Islam emphasizes personality formation rather than knowledge concepts. A professor at the Islamic higher education is recognized as having mastery of the kitab kuning studied by santri of dayah. Even the professor memorized the narrative and pages of one kitab kuning. But if he does not follow the systematics of education in dayah, then he still has not taken an ideal Islamic education system. Because if his skills only master the text, concepts in a literature, Orientalists can do it better. For this reason, every time a debate happens between dayah santri and modernist Muslims, dayah santri often lose. This is because they are taught science not only for knowledge, conception and memorization of references to citations, but they learn it for charity, for selfhood, to fulfill the needs of the soul, not to accumulate concepts and theories (Shiddiqi, 1977, p. 9).

Especially santri of dayah or traditional Islamic boarding schools (pondok) santri in Indonesia generally do not become terrorists, extremists, radicals, and subversive minds (Nugroho, 2019, p. 55). Those who have such thoughts are generally from modernist groups. Some Muslim modernist groups are reactionaries. They learn religion instantly, not deeply. In formal learning, the targets to be pursued are curriculum, syllabus, and numbers on the evaluation sheet. In a non-formal system, the goal is to master the concept with the aim of having provisions for debate (Supaat, 2015, p. 65).

The ideal religious education system is like being studied in dayah. Studying religion is not as easy as sewing courses or radio mechanics courses that can be mastered in just a few months. At dayah, a few months can sometimes only finish a few pages from one kitab. Compare this with the reactionaries who only studied religion in a week Islamic boarding school (pesantren kilat) and then immediately used robes and turban to claim others were heretical. Most of them are people who are only aware of the importance of religion after all their lives dedicated to the pursuit of lust. Unfortunately, their repentance requires sacrifice (Alqaf, 2018, p. 166).

With their busy learning of the basic things in religion, the santri of dayah did not have time to respond to the provocations launched. They cannot be deceived by jargon of jihad and so on, because they understand what jihad is and what it is like in life. This is in 
contrast to those who study religion halfway through pesantrenkilat or halaqah (meeting in a short and routine to discuss Islamic knowledge) (Kersten, 2015, p. 43).

Santri of dayah in particular and traditional santri of pondok generally, are too busy with essential things such as 'ibadah mahdhah (principal worship). They are also biased to be busy to purify the soul with varieties of salvation named zikir, tafakkur and khalwat. And more importantly, they will not act except on the orders and orders of their teacher (ulama dayah) (Saby, 2001, p. 1-35).

\section{Dayah: Limitations as Strengths}

The heart of a dayah is the charisma of its ulama (Nirzalin, 2011). Someone entrusts his child to the dayah with the main consideration is who is the ulama. It could have been that for several years a santri had not received any teaching fromabon, the ulama of the dayah leader. But theabonstudents who were considered to have mastered knowledge so that learning with them could be an introduction to the teaching of an abon. (Nirzalin, 2011, p. 159).

However, all santris can have many opportunities to get direct lessons from abon through public recitation which is often delivered at mosques or large halls (balee rayeuk) in dayah. Usually on such occasions, the abon only discusses general themes such as adab, dayah regulations and some general themes about religion. That was enough to be a spirit for the santri to continue to survive in the dayah. Santris who are very in love with the ulama will study in earnest in the hope that they can immediately enter the class taught directly by the abon.

At dayah, the learning standard is seven levels. If you have observed seven levels, you will be given a diploma to open bale in each village. If you want to serve, you can continue to study the highest kitab up to twelfth grade. Furthermore, a santri can also serve the dayah for life (Zarkasyi, 2018, p. 226).

The grade level before the first level is called tajhizi by studying Kifayatul Gulam, Safinatunnaja, Dhammon, Awamel, Alquran, Tajqid, Matan Taqreb and Aqidah Islamiyah. Furthermore, the first level studied Jurumiyah, Matan Bina, Muhimmatul Ulum, Tafsir Akhlak, Bajuri 1 and 2 and Mutammimah or Kawakib. The second level studied Matan Jauharah, Ta'lim Muta'allim, Kailani, Ia'natutthalibin 1 and 2. The third level studied Kifayatul Awwam, Daqaiqul Akbar, Kailani, Matan Sulam and Nufhat. The fourth level studied Ia'anatut at-Thalibin 3 and 4, Shehk Khalid, Hud Hudi, Idhamul Mubham, Salsul 
Madkhal, Bayan by Ahmad Shawi and Tankih. The fifth level studied Mahalli 1 and 2, Sabban Malawi, Lataiful Isyarah, Jauhar Maknun, Al-Fiyah, Ummul Barahin, Tafsir Jalalain and Mahalli 3 da 4. The sixth level studied Ummul Barahin, Ghayal Ushul, AlFiyah, Jauhar Maknun, Sabban, Sirajutthalibin, Tafsir Jalalain, and Muthasaan Hadith. The seventh level studied Mahalli, Tuhfah Muhtaj, Baiquni, JauharMaknun, Tafsir Jalalain and Al-Fiyah (Zarkasy, 2018, p. 229).

Prestige when becoming an honorary lecturer is preferred. In fact, by becoming an honorary lecturer, the money earned is not very different from those who serve in the dayah. So, if the expedition prefers to become an honorary lecturer rather than a dayah is the reason for money, then that is a big mistake. Even if compared, Islamic knowledge that is owned by studying at IAIN, is nothing compared to studying at dayah. But people prefer sekolah rather than studying at dayah.

Dayah does not have facilities, management and curriculum that can be considered adequate, systematic and measurable. Educational facilities in dayah are very limited. But this limitation can manifest militancy and independence for santri. Dayah does not have systematic management because all of that is only determined by the conditions that determine the learning process. The curriculum also cannot be measured because the only determinant of the benchmark is teungku. A teungku has the authority to determine the discussion and determine who is considered to have and has not mastered a book. In this case, in contrast to universities, dayah is not dependent on time or beginning, but is only determined by whether or not a santri has mastered the lessons given (Hadi, 2014).

The santri, alumni and teungku admitted that many things had to be renewed in the dayah to face a changing era. But if it is observed directly in a rather long time, then there is actually no administrative management in the dayah. Learning is done just like that with a predetermined schedule. Unlikesekolah and madrasah that have administrative departments, dayahs don't need that. The time to study and do daily activities such as cooking, washing clothes and so on has been determined. Santri is not forced to study with a large portion of time. Because in confirming their daily activities it takes a lot of time. And that is part of education.

The education curriculum in dayah should not be equated with schools and madrasah. Planning, process and evaluation is absolutely left to teungku. Teungku determines the feasibility of someone studying at the level of the kitab, how to learn how 
and how to determine whether a santri can be said to be khatam, become an expert or not in one kitab. Even the learning schedule is adjusted to certain conditions. For example in the harvest season and planting rice, the duration of learning is shortened because teungku and santri are exhausted. This condition will not be understood by the modern curriculum and learning evaluation system. This is the first reason why education in dayah should not be intervened by modernist and secular groups, both personally, non-governmental organizations and state organizations (Ilyas, 2019, p. 33).

Many dayahs do not have adequate learning and boarding facilities. Many people want government assistance and NGOs to provide assistance to dayah. But the actual help is slowly undermining the identity and uniqueness of the dayah. Independence is an important part of the existence of dayah. If independence is replaced with assistance, it can paralyze dayah.

The presence of the Aceh Government through Dinas Pendidikan Dayah is considered a new hope for dayah. But everyone knows there's no free lunch. When governments spend money, they demand a lot of things and make a lot of standardization. This standardization cripples the dayah with the emergence of various instant systems such as in sekolah and madrasah. Even though with full authority possessed by teungku and ulama, they can determine whether a santri has understood or not yet learned a lesson.

Many people also hope that dayah will develop life skills so that students can have expertise such as sewing, mechanics, entrepreneurship and so on after graduating from dayah. This also has the potential to damage the identity of the dayah. Students should focus on religious education with the traditional system they have. The hope of the people of the dayah alumni must be one of them being the guardian of the religious community (Amiruddin, 2007, p. 77).

\section{Demarcation of Dayah, Modernist Group, and Reactionary}

In this case the original line of Islamic traditionalism in Aceh needs to be clarified. Post-colonialism, the Islamic paradigm in Aceh has been divided into traditionalists and modernists. Traditionalists are santris and ulama of dayah who are not interested in modernizing Islam. They chose to maintain the original principles and systems of Islamic education. While in the early generations, modernists were those who departed from traditional Islamic education but later chose the path of modernization as a view that desired the advancement of Islam and was not left behind by changing times. Tuanku Raja 
Keumala who founded Madrasah Khairiahin Banda Aceh, Sayid Husin Syahab who founded the Madrasah Ahlussunnah Waljama'ah in Idi East Aceh and Teungku Abdurrahman Meunasah Meucap Matangglumpang dua who founded Al-Muslim, is a sign of the beginning of the emergence of Islamic modernism in Aceh (Saifullah, 2016, p. 36).

Modernist groups want Islamic education not to be taught textually but also contain rhetoric. They want in Islamic education institutions not only to teach kitab kuning and only learn fiqh, tauhid, tajwid, nahwu, sharaf, balaghah and akhlaq, but also study general sciences such as mathematics, physics and biology. The fruit of this thinking is the birth of madrasah education which, in a hierarchical manner, includes raudhatulaflah, ibtidaiyah, tsanawiyah, aliyah dan jami'ah (Islamic Higher education) (Saifullah, 2016, p. 37).

It turns out that religious learning in the same way as sekolah learning applied by modern Islamic education institutions has left the principle of deepening the mastery of knowledge and habituation in the implementation of religious learning as a characteristic of traditional education. Religious learning in madrasah becomes more instant, not profound, and less systematic. Indeed, some general science can be mastered, but also not deep. Religious knowledge also becomes insignificant. Madrasah lose focus (Kamaruzzaman, 2015, p. 52). Religious learning that is not systematic and not profound is not complete, causing the religious sciences to be studied less integrated with the soul. School learning systems are only for conceptualization.

The responsibility of religious outreach makes the learner less able to understand which principles and which are less principled in religion. This problem is experienced by the modern Islamic movement in religious learning held in the form of short meetings. In these models, religion is only studied at a glance (Miswari, 2018, p. 33).

The proliferation of models of religious learning in a short duration is a symptom of the rise of human spirituality because in nature, humans are spiritual beings. But for one reason or another they prioritize material needs so that they dominate spiritual needs which are characterized by preferring sekolah to dayah. As a result, they had to choose a short duration religious learning system provided by the modern Islamic movement to fulfill those spiritual needs (Ismail Fahmi, 2015, p. 99).

An instant model of studying religion makes it difficult for them to determine priorities. This is one of the disadvantages of the modernist group. They failed to place the sacred on the sacred tempt. They failed to put the profane in a profane place. Just like that they are sacred and profane and sacred (Budhy, 2010, p. 38). 
For example, when they fight for a "tauhid flag", they cannot understand where the position of the flag is and where the position of tauhid is. They put the sacred tauhid sentence (kalimah tawhid) in a profane place like a flag. People who study religion well understand that sacred sentences should not be attached to a profane place so they burn them to keep something sacred (Miswari, 2019, p. 65)

There is a time when the traditionalist group warns the reactionaries not to treat sacred matters profanely. But the reactionists criticized traditionalists. As a result, what was feared happened. The sentence of monotheism as a sacred sentence becomes truly insulted. The "kalimahtawhid" written on the flags is very badly enforced, put in inappropriate places (Masrur, 2019, p. 165).

Reactionary groups are very easily provoked (Kersten, 2015). Whether they are aware or not, they are dragged into fighting for the political interests of certain groups. They will not experience excitement if they only study religion in the right way under the guidance of credible ulama (mu'tabar).

A credible ulama will not lead santris and the community to the streets that do not benefit religion and nation. The scholars emphasized that their students would be strong and profound in their knowledge, much of salvation so that they would not become reactionary humans. The ulama have profound religious knowledge. They not only see things through rational analysis but they are able to see them with transcendental intuition. The decisions they make are generally on the road that brings goodness to society (Muhammad Abdullah, 2018, p. 77).

For example, the ulama in Aceh around the period of the Indonesian revolution, the ulama emphasized loyalty to the country. While some modernist groups actually advocate for subversive actions that can divide national unity. With this wise perspective, the ulama are always used as a place for officials and government officials to ask for advice, opinions and views (Baiquni, 2019, p. 160).

The reason why theulama are approached by the government is because they are broad-minded, they love the country and are away from things that are radical and subversive. Compared with the reactionary group intellectuals who felt they were always oppressed by the government, always seeing the government's actions wrong. They are radical and intolerant. The reactionary group intellectuals have always issued invariable utterances, provocative and often lead followers to things that are detrimental to the 
stability of the country. They lead the community to voice the interests of certain groups by using Islamic symbols and jargon.

\section{The Direction of Moderation Education Islam}

With all the explanations I have explained about dayah, modernization has become difficult for dayah. But is that right? But beforehand, it was necessary to first clarify what modernization was and how modernization was in Islam. Modernization is everything that has a novelty. Thus, all the books (kitab) studied in Islam are modern books because they are all studied based on the development of their main books such as the fiqh of Imam Shafi'i, the tauhidfrom Abu Hasan Al-Asy ' ari and Sufism from Abu Hamid Al-Ghazali (Ismail Fahmi, 2017, p. 70).

The writers of the kitab studied at dayah have developed and adapted the main points for their respective themes according to their time. Teungku who teach kitab always involving contextual cases so that learning in dayah can be ascertained very modern. They cannot be said to learn something that is only textual or utopian because the kitab written and teach are always moderated for their time and contextually directed.

Dayah looks traditional when compared to sekolah that learn all the knowledge presented by the West. All theories released by people called scientists are studied assuming that they are real. But actually theory is a theory. Anyone has the right to issue a theory. The theory is also like religion. Both are followed because of belief. Even many theories that cannot be proven by anyone include the originator of the theory. In this case, religion is better because the apostle who brought the religion experienced firsthand experience. Darwin, for example, issued the Theory of Evolution. Many people believe that. Even the theory has become like water, easily dissolved in science (Horgan, 2015, p. 173).

We don't want to reject science. Science is also like culture. Pure from the results of human creativity. But a group of irresponsible people has made science not contextual in life. Various theories and speculations that are irrelevant to human life, with their natural disposition into science and even become the paradigm. Science has become like an idol

The biggest sins of fake scientists include making science a tool of resistance to religion. A group of people tried to separate science from religion in medieval times in Europe. Even several centuries before in the Middle East, science had run very 
hairmonically with religion (Miswari, 2016, p. 43). Why did it happen? Is it because of the significant differences between Islam and Christianity? No. Not because of that. Every religion has the same basic teachings (God, apostles and the hereafter). The problem is, a group of people wants to build a world level that is separate from religion.

Religion is slandered in such a way. Religion is accused of being anti-science. In fact, religion is the one who has raised science. Impossible religion is not in line with science. Great slanders were launched to corner religion so that religion was only left behind in the aspect of spirituality. Meanwhile, science has been infiltrated by theories that cannot be accounted for is campaigned in such a way as if science can be a solution to all problems of human life (Hrari, 2014, p. 21).

Not long ago, a book titled Sapiens was written by Yuval Noah Harari. The book wants to show that religion is an irrational doctrine that only inhibits the development of human intelligence (Harari, 2015, p. 65). Dan Brown also wrote Origin, a novel which tells the story of a futurologist who sees that basic human questions are like where and where they can be satisfactorily answered through science. While religion offers only utopia that is not satisfying.

Actually attacks on religion have occurred since the religion was introduced. In modern times, attacks to religion like told in Origin and Sapienstill in the corridor of Auguste Comte's theory which saw religion as a primitive stage in the evolution of human intelligence. Comte believes science is the culmination of the evolution of human intelligence (Gharawiyan, 2012, p. 38).

Actually, Comte's perspective also originated from the scheme of the theory of evolution. According to Comte, human reason increases from theological, metaphysical to positivistic (Hamzah, 2018, p. 32). In fact this is not the case. Theology, metaphysics and sensory perception can appear together in humans. The three are not contradictory things. Religion, ideology and science each complement the human soul. Empirical beliefs, beliefs and knowledge, are things that arise each at the level of the soul in each individual (Ismail Fahmi, 2018, p. 55).

There will be nothing wrong if the Comte theory is reversed, it becomes empiricalpositive science first then the next metaphysics of theology. In fact, this is more in line with the way humans acquire knowledge that is from sensory perception, intellectual reasoning and intact understanding (Naquib Al Attas, 1995, p. 99). 
Today the community is preoccupied with various discourses of harmonizing science and religion. Many concepts emerge. UIN Jakarta with Integration of Science, UIN Yogyakarta with Integrative-interconnection, and so on. But it turns out that these concepts are pragmatic because they look for reasons that can be accepted in order to change IAIN to UIN. We do not want to look at lucrative funding for UIN compared to IAIN, but want to review how religion and science reconciliation after the divorce was passed in the Middle Ages, which was marked by rensaissance.

A paradoxical attitude occurs in our way of thinking. On the one hand we accept with pleasure renesains, an agenda of the separation of religion from science. We consider science as something advanced. Then we try to re-integrate it lately (Amin Abdullah, 2003, p. 24). In fact, the classification, grouping, and division of authority areas are part of the achievements of academic theory.

Separation of religion with science is a mistake of a group of people, in this case Galileo Galilei as an icon, who opposed the teachings of the church by presenting unusual theories. Religion, the church as an institution that greatly appreciates science facilitates Galilei to prove his theories. He failed. But he was constantly attacking the church. Research funding is given. His research failed. In fact, the sponsor was attacked. Likewise, Newton's theories are thought to be the pathenisation of Leibniz's theories. If this assumption is correct, then it is the greatest plagiarism in the history of science (Garber, 2009, p. 90).

I explained that this was not intended to oppose science. In fact, I want science to return to its corridor as a fruit of intellectualism. So that he can harmonize with other human wealth such as religion, art and philosophy (Ismail Fahmi, 2013, p. 21).

How can this be realized? It is by continually testing scientific theories that are raised, tested whether they are in accordance with religion, in accordance with art, in accordance with philosophy, or in accordance with the natural principles of other humans. If not, then a science theory is suspect as a preudoscience.

\section{Modernization of Al-Aziziyah}

Dayah Al-Aziziyah, especially in the central dayah in Mudi Mesra Samalanga, Bireuen Aceh, seemed to understand well the direction of modernity and the dangers of westernization contained in it, so that they can be said to be the wisest dayah in 
modernizing themselves. They do not ignore modernization. But they did not want to be trapped in aspects of modernization which could damage the identity of the dayah.

This spirit was inherited by Abon Aziz Samalanga to his students. Mudi Mesra Samalangan's leadership was continued by Abon Hasanul Basri. The principle of dayah moderation is well guarded by Abon Hasanul Basri. One form of this spirit is establishing Islamic Higher Education (SekolahTinggi Agama Islam, STAI) Al-Aziziyahin Samalanga. There, the pattern of education is carried out like dayah manyang.

At its inception, STAI Al-Aziziyah only accepted students from Dayah Mudi Mesra Samalanga and certain dayah alumni, especially Al-Aziziyah school. Qualifications of prospective students according to the qualifications of ma'had 'ali. Prospective students must be able to read and understand kitab such as Fathul Mu'in, Afiyah Ibn Malîk, Ghayah Al-Ushul. The hope is that since the beginning the campus can become like ma'had ali. But the standard was lowered because they had to meet the qualifications and criteria made by the Ministry of Religion. So now STAI Al-Aziziyah no longer only accepts dayah AlAziziyah alumni. But they still require santri to stay at MUDI or other dayah recommended by MUDI MesraSamalanga (Sariyulis, 2018, p. 34).

Dayah Mudi Mesra Samalanga also participates in other academic moderations such as publishing bulletins, journals and magazines. The orientation is to spread da'wah. Even they have Facebook Fanspage, Youtube, Instagram and other social media. The students (mahasiswa and santri) were given courses that could make dayah not left behind by modernization such as providing courses in mastering technology and computer science.

The phenomenon experienced by Mudi Mesra Samalanga is a representation of how traditionalism must negotiate with modernity or moderate Islam represented by the Government through the Ministry of Religion. Modernists want an educational institution to have standards that can be formulated and evaluated objectively. But if the dayah follows these standards, they can lose their identity and the uniqueness of their traditional system.

In this case, the presence of the Aceh Dayah Education Agency (Dinas Pendidikan Dayah Aceh) is actually a threat to the uniqueness of the traditional education system that dayah has. In fact, dayah has become the only educational institution that has managed to maintain the identity and Islamic principles of the Acehnese people. If the concern of modern groups and secular groups is not well managed, then the characteristics of the 
dayah will be lost. The education system will change, not unlike the madrasah (Azyumardi Azra, 2014, p. 119).

The unique identity of dayah who studies religion deeply makes them complete in understanding religion. The result is that they can understand Islam according to their enthusiasm. This pattern contradicts the group that studies religion on the surface, only relies on religion on symbolic aspects, is easily provoked like a reactionary group. Meanwhile, santri of dayah can understand correctly the position of religion and how to position it when faced with profane matters, such as politics and modernity. They are Islamic education alternatives that deserve attention (Azyumardi Azra, 2014, p. 120).

\section{Conclusion}

There are only two ways to make religion not a tool of violence, fanaticism, radicalism and terrorism. The first is to study religion in a systematic, in-depth and comprehensive way as done in dayah. The second way is not to learn religion at all, in other words precisely; religion is not studied at all.

Religion will continue to be a tool of violence and threats when it is studied like learning sewing or like in radio repair courses. Religion as something sacred in human life should not be studied instantly and self-taught. Religion must be studied through authoritative kitab written by scholars who have a trusted scientific pedigree.

Also the books that are learned must go through syarah (direct explanation) from ulama who have truly understood a kitab. Radical, reactionary and terrorist thoughts generally come from those who study religion autonomously through books written by radical people (Ikhsanul Amin, 2019, p. 21). Such people are very easily provoked so that they are aware or not bring religion to pragmatic matters.

Only by studying religion in a good and systematic way can moderation be done based on the direction that is in accordance with human nature. If not, moderation only directs humans to losses.

\section{Reference}

Abbas, S. (2010). Sejarah dan Keagungan Mazhab Syafi'i. Jakarta: Pustaka Tarbiyah Baru

Abdullah, M. Amin. (2006). Islamic Studies di Perguruan Tinggi: Pendekatan IntegratifInterkonektif. Yogyakarta: Pustaka Pelajar. 
. (2003). "New Horizons of Islamic Studies through Socio-Cultural Hermeneutics." Al-Jami'ah: Journal of Islamic Studies 41, no. 1 : 1-24.

Ahmad, K. B. (2005). "Educational Practice: Lessons to Be Learned from Madrasah and Religious Schools in Contemporary Southeast Asia." Indonesian Journal of Islam and Muslim Societies 5, no. 1 (June 1, 2015): 29. https://doi.org/10.18326/ijims.v5i1.29-48.

Ahmad, Sayed M.(1992). Ketika Pala Mulai Berbunga: Seraut Wajah Aceh Selatan. Tapak Tuan: Pemuda Aceh Selatan.

Al-Attas, Syed Muhammad Naquib. (1995). Islam Dan Filsafat Sains. Bandung: Mizan.

Amin, Muhammad Ikhsanul, Tiyas Nur Haryani, Nur Hidayatul Arifah, and Arina Mardhiyana Husna. (2019). "Islamic Education in Supporting De-Radicalization: A Review of Islamic Education in Pondok Pesantren." Nadwa 12, no. 2 (January 7, 2019): 259. https://doi.org/10.21580/nw.2018.12.2.2581.

Amiruddin, M. Hasbi. (2007). Ulama Dayah Pengawal Agama Masyarakat Aceh. Lhokseumawe: Nadiya Foundation.

Azra, Azyumardi. (2014). Pendidikan Islam: Tradisi dan Modernisasi di Tengah Tantangan Millenium III. II. Jakarta: Kencana.

Baiquni. (2019). "Tengku Haji M. Hasan Krueng Kalee: Sufi, Guru Dan Politisi." Academia. Accessed May 2019. https://www.academia.edu/31552958/Tengku_Haji_M._Hasan_Krueng_Kalee_Sufi_ Guru_dan_Politisi.

Bruinessen, Martin. (1990). "Kitab Kuning; Books in Arabic Script Used in the Pesantren Milieu; Comments on a New Collection in the KITLV Library." Bijdragen Tot de Taal-, Land-En Volkenkunde / Journal of the Humanities and Social Sciences of Southeast Asia 146, no. 2 (January 1, 1990): 226-69. https://doi.org/10.1163/22134379-90003218.

Cache, Bernard. (2011). "Desargues and Leibniz: In the Black Box a Mathematical Model of the Leibnizian Monad." Architectural Design 81, no. 4 (2011): 90-99. https://doi.org/10.1002/ad.1273.

Gama, Cipta Bakti. (2015). "Reduksionisme Eksplanatif untuk Antropologi Transendental Jawadi Amuli." Kanz Philosophia: A Journal for Islamic Philosophy and Mysticism 5, no. 2 (2015): 147-64. https://doi.org/10.20871/KPJIPM.V5I2.133.

Garber, Daniel. (2009). Leibniz Body, Substance, Monad. Leibniz Body, Substance, $\begin{array}{llll}\text { Monad. } & \text { Vol. } & \text { 9780199566, }\end{array}$ https://doi.org/10.1093/acprof:oso/9780199566648.001.0001.

Gharawiyan, Mohsen. (2012). Pengantar Memahami Buku Daras Filsafat Islam. Jakarta: Sadra Press. 
Hadi, Abdul. (2014) “Dinamika Sistem Institusi Pendidikan Di Aceh.” Peuradeun 2, no. 3 Hamidy, Rasul. (1982). "Kharisma Ulama dalam Persepsi Masyarakat Aceh.” Banda Aceh/ Hamzah. (2018). Filsafat Ekonomi Islam. Lhokseumawe: Unimal Press.

Harari, Yuval Noah. (2014). A Brief History of Humankind: Sapiens. Signal. https://doi.org/10.1017/CBO9781107415324.004.

(2015). Sapiens: A Brief History of Humankind. New York: Harper, 2015.

Hasjmy, A. (1978). Bunga Rampai Revolusi dari Tanah Aceh. Jakarta: Bulan Bintang. (1981). Sejarah Masuk dan Berkembangnya Islam di Indonesia. Medan: Pustaka Al-Ma'arif.

Horgan, John. (2015). The End of Science: Facing The Limits of Knowledge in The Twilight of The Scientific Age. New York: Basic Books.

Ilyas, Mukhlisuddin. (2019). “Masa Depan Dayah.” In Islam, Formalisasi Syariat Islam dan Post-Islamisme di Aceh, edited by Miswari, 1st ed., 33. Banda Aceh.

Iqbal. (2016). Rekonstruksi Pemikiran Religius dalam Islam. Bandung: Mizan.

Kersten, Carool. (2015). Islam in Indonesia: The Contest for Society, Ideas and Values. New York: Oxford University Press.

Kurdi, Muliadi. (2015). Ensiklopedia Ulama Besar Aceh. Banda Aceh: NASA.

Ma'rifah, Siti. (2015). "Pesantren Sebagai Habitus Peradaban Islam Indonesia." Jurnal Penelitian 9, No. 2 (August 1, 2015): 347. https://doi.org/10.21043/jupe.v9i2.1325.

Makin, Al. (2018). "Bisakah Menjadi Ilmuwan di Indonesia?: Keilmuan, Birokrasi Dan Globalisasi." Yogyakarta.

(2016). Challenging Islamic Orthodoxy. Popular Culture, Religion and Society; A Social- Scientifi c Approach. Vol. 1. Popular Culture, Religion and Society. A Social-Scientific Approach. Cham: Springer International Publishing, 2016. https://doi.org/10.1007/978-3-319-38978-3.

- (2016). "Unearthing Nusantara's Concept of Religious Pluralism: Harmonization and Syncretism in Hindu-Buddhist and Islamic Classical Texts." Al-Jami'ah: Journal of Islamic Studies 54, no. 1 (June 25, 2016): 1. https://doi.org/10.14421/ajis.2016.541.1-30.

Maksum, Ali. (2016). "Model Pendidikan Toleransi di Pesantren Modern dan Salaf." Jurnal Pendidikan Agama Islam (Journal of Islamic Education Studies) 3, no. 1 (February 7, 2016): 81. https://doi.org/10.15642/jpai.2015.3.1.81-108.

Masrur, Muhammad.(2019). “Merenungi Aksi Bela Tauhid, Benarkah Membela Agama?” 
Bincang Syariah. Accessed May 8, 2019. https://bincangsyariah.com/kalam/aksibela-tauhid-dan-bela-agama/.

Miswari. (2018). "Banser Bakar Bendera Tauhid." Miswari Zawiyah. Accessed May 8, 2019. http://www.miswari.com/2018/10/banser-bakar-bender-tauhid.html.

_. Filsafat Langit dan Bumi. Lhokseumawe: Unimal Press.

_. (2016).Filsafat Terakhir. Lhokseumawe: Unimal Press.

Munawar-Rachman, Budhy. (2010). Argumen Islam untuk Pluralisme. Jakarta: Grasindo.

Musliadi. (2017). Abuya Syaikh Muda Waly Al-Khalidy (1917-1961): Syaikhul Islam Aceh, Tokoh Pendidikan dan Ulama 'Arif Billah. Banda Aceh: PeNa.

Muthohar, Sofa. (2016). “Antisipasi Degradasi Moral di Era Global.” Nadwa, 2016. https://doi.org/10.21580/nw.2013.7.2.565.

Nasution, Ismail Fahmi Arrauf. (2018). Filsafat Ilmu Pengetahuan. Lhokseumawe: Unimal Press, 2018.

(2017). "Humanisasi Pendidikan Islam Melalui Antropologi Transendental Hamzah Fansûrî." Edukasia: Jurnal Penelitian Pendidikan Islam, 2017. https://doi.org/10.21043/edukasia.v12i1.2310.

. (2013). “Mencerna Akar Filsafat dalam Islam.” Ulumuna 17, no. 1 (2013): 1018.

(2017). "Termination of Wahdatul Wujud in Islamic Civilization Aceh: Critical Analysis of Ithaf Ad-Dhaki, The Works of Ibrahim Kurani." Ad-Din 11, no. 2 (2017).

Nirzalin. (2011). "Krisis Agensi Politik Teungku Dayah di Aceh." Gadjah Mada University.

Nugroho, Puspo. (2019). "Internalization of Tolerance Values in Islamic Education." $\begin{array}{lllllll}\text { Nadwa } & 12, & \text { no. } & 2 & \text { (January } & 7, & 2019):\end{array}$ https://doi.org/10.21580/nw.2018.12.2.2397.

Russell, Bertrand. (2001). History of Western Philosophy. London: George Allen and UNWIN.

Saby, Yusny. (2001). "The Ulama in Aceh: A Brief Historical Survey.” Studia Islamika 8, no. 1 (2001): 1-35.

Saifuddin, Ahmad. (2016). "Eksistensi Kurikulum Pesantren dan Kebijakan Pendidikan." Jurnal Pendidikan Agama Islam (Journal of Islamic Education Studies) 3, no. 1 (February 7, 2016): 207. https://doi.org/10.15642/pai.2015.3.1.207-234. 
Saifullah. (2016). Pembaruan Pendidikan Islam di Aceh. Yogyakarta: Pustaka Pelajar.

Samalanga, Teungku Nuruzzahri. (2008). "Latar Belakang Ma'had Aly." In Kajian Tinggi Keislaman, edited by Muliadi Kurdi, 183. Banda Aceh: Kesra Aceh.

Shiddiqi, Nouruzzaman. (1997). Fiqh Indonesia; Penggagas Dan Gagasannya. Yogyakarta: Pustaka Pelajar.

Supaat, Supaat. (2013). "Transformasi Madrasah dalam Sistem Pendidikan Nasional." Jurnal Penelitian dan Evaluasi Pendidikan 15, no. 1 (January 11, 2013): 155-86. https://doi.org/10.21831/pep.v15i1.1092.

Tgk Zarkasy. (2006). “Wacana Pemikiran Santri Dayah Aceh.” Banda Aceh: Wacana Press.

Zuhriy, M. Syaifuddien. (2011). "Budaya Pesantren dan Pendidikan Karakter pada Pondok Pesantren Salaf." Walisongo: Jurnal Penelitian Sosial Keagamaan 19, no. 2 (December 6, 2011): 287. https://doi.org/10.21580/ws.2011.19.2.159. 
